\title{
The Political Sources of Social Solidarity
}

\section{Citation}

Hall, Peter. 2017. "The Political Sources of Social Solidarity." In The Strains of Commitment: The Political Sources of Solidarity in Diverse Societies, 349-398. Oxford: Oxford University Press.

\section{Published Version}

10.1093/acprof:oso/9780198795452.003.0008

\section{Permanent link}

http://nrs.harvard.edu/urn-3:HUL.InstRepos:33667662

\section{Terms of Use}

This article was downloaded from Harvard University's DASH repository, and is made available under the terms and conditions applicable to Open Access Policy Articles, as set forth at http:// nrs.harvard.edu/urn-3:HUL.InstRepos:dash.current.terms-of-use\#OAP

\section{Share Your Story}

The Harvard community has made this article openly available.

Please share how this access benefits you. Submit a story.

Accessibility 
Forthcoming in The Strains of Commitment: The Political Sources of Solidarity in Diverse Societies, eds. Keith Banting and Will Kymlicka. Oxford: Oxford University Press.

\title{
Chapter 8
}

\section{The political sources of social solidarity}

\author{
Peter A. Hall
}

This essay explores the roots of redistributive social solidarity in the developed democracies. Banting and Kymlicka (this volume) define social solidarity as a worldview widespread among the populace, with civic, democratic and redistributive dimensions, whereby individuals tolerate views and practices they dislike, accept democratic decisions even if those run counter to their beliefs or interests, and support relatively generous provisions to help the disadvantaged. Although solidarity can also be judged by the policies of a community, in this formulation, solidarity refers to a set of attitudes widely shared within the community or nation. My focus is on the redistributive dimension of social solidarity, namely the willingness of people to see governments redistribute resources to the less advantaged, and my interest is in understanding how such attitudes come to be widely shared and sustained within a society. Although the sources of support for social rights are not identical to those for civil and political rights, this account can inform our more general understanding of the roots of social solidarity (Marshall 1950).

Two bodies of literature frame this analysis. The first is a literature in comparative political economy, which explains support for redistribution - understood as policies designed to make incomes more equal - largely as a matter of self-interest on the part of people who might benefit 
from this redistribution. This view finds classic expression in the influential Meltzer-Richard (1981) model, which predicts that effective support for redistribution will increase as the income distribution of a society becomes more unequal, because that increases the benefits the median voter might draw from redistribution. There is undoubtedly some truth in such formulations since people on lower incomes almost always express more general support for income redistribution than do people on higher incomes (Finseraas 2008).

From the perspective of social solidarity, however, this literature has at least two problematic features. First, it explains support for redistribution in terms that could be considered inimical to the concept of social solidarity, namely, on the basis of personal self-interest rather than out of a concern for others in society. At a minimum, we need a fuller understanding of how selfinterested actions might feed into something broader that can be described as social solidarity. The second problem is that this approach does not explain very well the differences in attitudes to inequality observed across nations. Because attitudes to inequality are multidimensional and the available measures for them limited, there is controversy about this point. However, studies looking for Meltzer and Richard (1981) effects find that the existing distribution of national income explains at best only some of the cross-national variation in attitudes to redistribution (Lübker 2007; Kenworthy and McCall 2008).

Figure 1 provides an illustration of the issues based on a measure that assesses general support for redistribution in each nation. ${ }^{1}$ Inside Western Europe, there appears to be a relationship between the distribution of disposable income in 1999 and support for redistribution, of the sort comparative political economists would expect. But the relationship disappears when a wider 
range of countries are considered. There are indications here that support for redistribution depends on more than existing levels of income inequality. We need accounts of the underpinnings for such support that take a wider range of factors into consideration.

Figure 1 The relationship between disposable income inequality and general support for redistribution

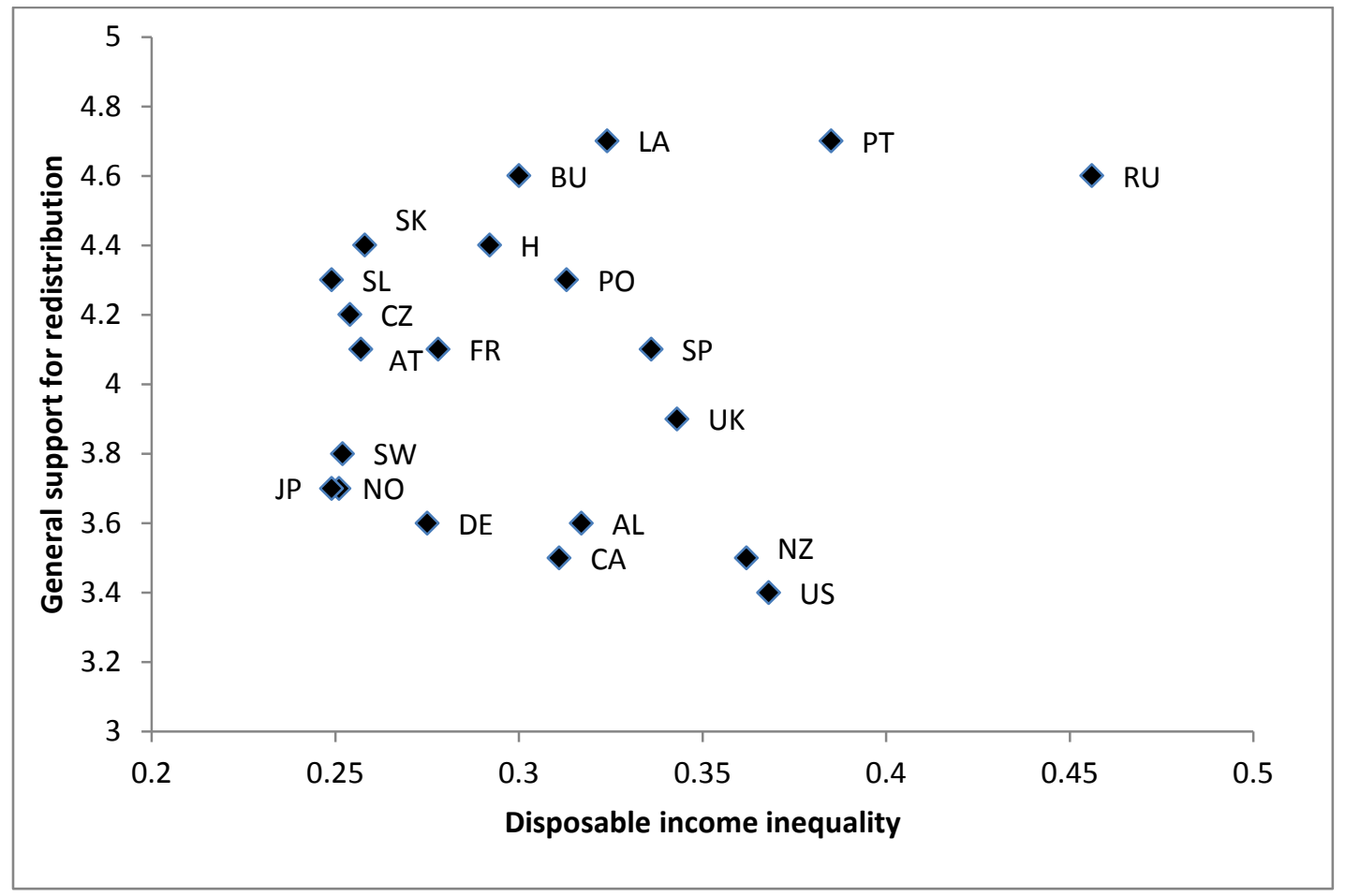

Sources: ISSP (1999); LIS; Dallinger (2010). $\mathrm{R}^{2}=0.03$; SE: 0.43

The second literature framing this discussion is an influential body of work that views national identity as the crucial basis for social solidarity. While political economists explain support for redistribution via mechanisms rooted in self-interest, the national identity literature argues that solidarity depends on concerns for others, thereby directing our attention to images of who belongs to the community. The central debates in this literature focus on whether attachment to 
the nation fosters social solidarity and whether some types of national identity promote solidarity more than others (Miller 1995; Abizadah 2002; Kymlicka 2001). On the first of these issues, however, the empirical evidence is mixed at best. At the individual level, Johnston et al. (2010) find that feelings of attachment to the Canadian nation are associated with slightly more support for redistribution. But Shayo (2009) finds lower support for redistribution among people who have higher levels of pride in their nation (see also Theiss-Morse 2009). On balance, it seems that stronger attachment to the nation does not promote support for redistribution in any unmediated way. Instead, the relationship between national identity and solidarity may depend on the type of national identity prevalent in a country, including features of national identity distinctive to that nation (Miller and Ali 2013).

Some claim, for instance, that the levels of inclusiveness required for solidarity, especially in multiethnic societies, will be present only where national identity takes a 'civic' form that associates the nation with shared commitments to a common set of principles or political institutions. Habermas (2001) describes this as ‘constitutional patriotism’; and Pehrson, Vignoles, and Brown (2009) note that levels of hostility to immigrants are lower in countries where civic conceptions are more prevalent than ethnic conceptions of national identity. By contrast, others contend that civic national identities do not provide a sense of communal belonging deep enough to sustain the tolerance, mutual trust and support for redistribution associated with social solidarity (Tamir 1993; Miller 1995). On this view, solidarity must be rooted in a national identity that has some sort of 'cultural' or 'ethnic' character, based on a shared culture, ethnicity, or territorial history. ${ }^{2}$ 
Does support for redistribution depend on national identities that are civic or ethnic? Once again, the evidence is not dispositive partly because the available measures are so limited, but we can form a preliminary assessment by comparing the character of each country's national identity with support for redistribution there. To assess a country's national identity, I use the average national score on indices for civic and ethnic nationalism derived from a factor analysis by Helbling, Reeskens, and Wright (2013) of respondents to a 2003 ISSP survey. ${ }^{3}$ When these scores are compared to general support for redistribution as measured in Figure 1, the bivariate relationships (not shown) are entirely insignificant. ${ }^{4}$

However, we might also consider the relationship between conceptions of national identity and support for redistribution to the poor, arguably a more direct feature of social solidarity. To assess the latter, I use a measure of the extent to which respondents ascribe poverty to factors beyond the control of the individual rather than to the laziness or lack of willpower of the poor. ${ }^{5}$ The results are reported in Figure 2. The presence of a more civic national identity does not seem to be related to support for redistribution to the poor. Moreover, in countries where ethnic conceptions of national identity are more prevalent, there is actually less support for such redistribution $\left(\mathrm{r}^{2}\right.$.43). In short, some minimal national identity may be a necessary prerequisite for redistribution, but stronger civic or ethnic identities do not seem to increase support for it. 
Figure 2 The relationship between national identity and support for redistribution to the poor

(a) Civic identity

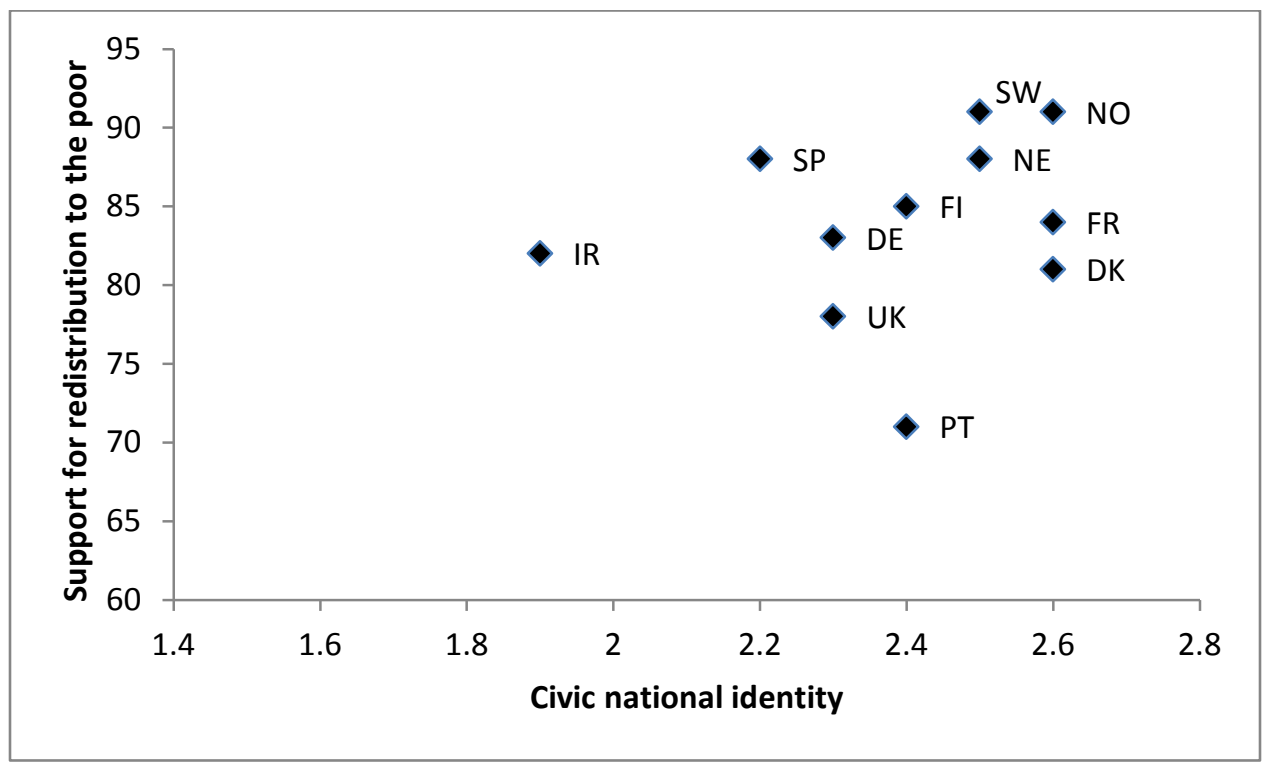

(b) Ethnic identity

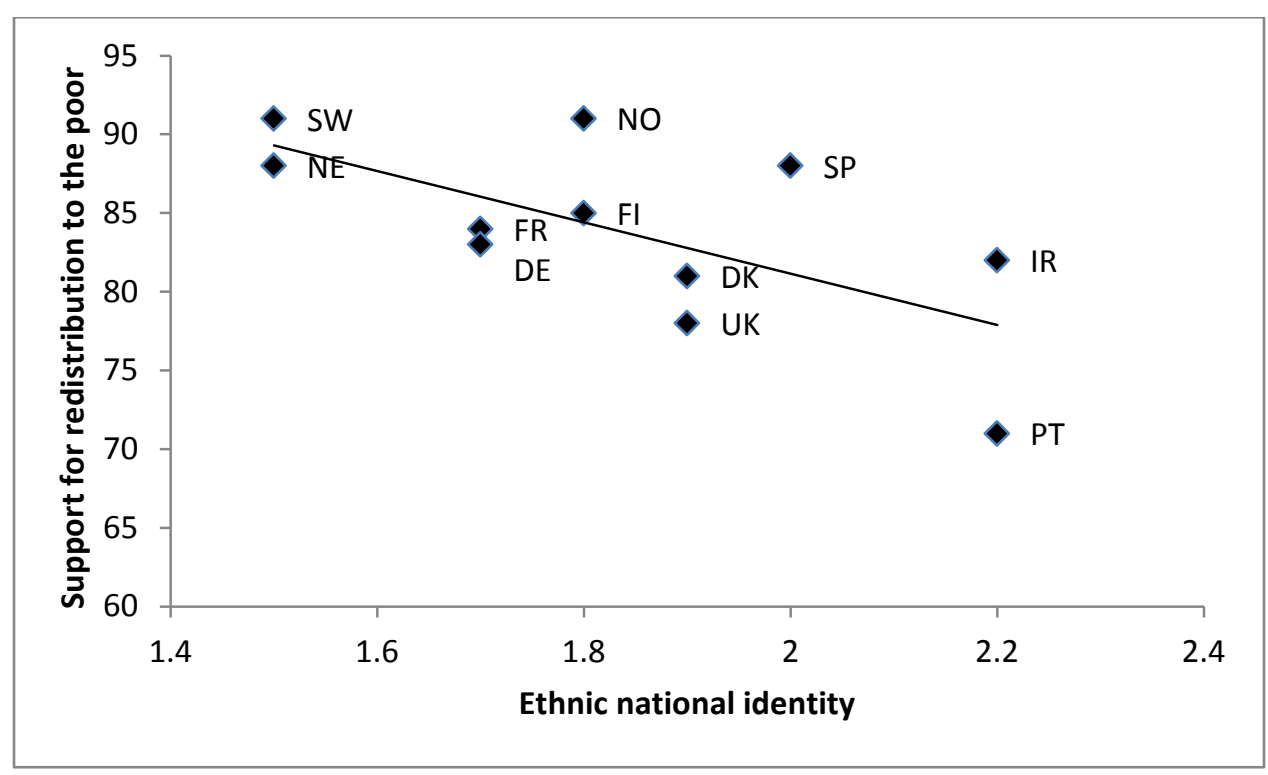

Sources: Eurobarometer 56.1 (2001); ISSP (2003); Helbling, Reeskens, and Wright (2013). For

2(a) $\mathrm{R}^{2}=0.05 ; \mathrm{SE}=6.08$. For 2(b) $\mathrm{R}^{2}=0.43 ; \mathrm{SE}=4.70$. 


\section{An alternative approach: Social solidarity as quasi-equilibrium}

There is certainly something to be explained here. As Figure 1 indicates, across the developed democracies, popular support for redistribution varies dramatically. While two-thirds of Germans thought that it was the government's responsibility to reduce income inequality in 1992, only 38 percent of Americans did so (Svallfors 1997, 288; 2012). If existing explanations give us little purchase on the problem, how are such variations in redistributive solidarity to be explained?

In what follows, I propose an alternative approach to this problem, breaking it down into two component parts. The first is the problem of understanding how the attitudes embodied in redistributive solidarity, once established, are sustained, while the second is the problem of explaining how such attitudes develop in the first place, which I will treat in that order. My perspective on the first problem can be labeled a 'quasi-equilibrium' approach to the issue. The micro-foundations for this perspective lie in the observation that the conceptions of 'self-interest' and 'altruism' that figure prominently in most discussions of redistribution are misleading because they are usually construed in terms that are too narrow or overly abstract. In the abstract form in which they are typically adduced, those concepts are too distant from the social, economic and political contexts that give such motivations concrete meaning and operative force in the world.

In many accounts that turn on self-interest, for instance, the latter is construed primarily as the desire of the individual for more income. This is recognizable enough as a potential motive and 
important to some degree, but it is far from the only way in which people construe their selfinterest. People often act out of self-interest, but they do so in pursuit of a wide range of goals, which includes immediate material interest but can easily extend to other dimensions of wellbeing, including ones that turn on the provision of collective as well as individual goods. For example, a voter might well ask: am I going to support this candidate because he promises to lower my taxes or that one because he is going to protect my environment? Thus, there are often trade-offs between the goals engaged by self-interest; and individuals are continuously making judgments about which ones to privilege at any given time that are deeply conditioned by the institutional and cultural frameworks in which they live. If the politicians seeking my vote preside over a highly-corrupt state, for instance, I might well vote for the one who will lower my taxes rather than trust the other to improve the environment, although in a different institutional context I might do just the reverse.

Much the same is true of the generalized concepts of altruism that figure in analyses of redistribution. A person who is said to be acting out of altruism is, in fact, usually acting out of a complex set of understandings about his or her obligations to specific kinds of people and principles; and those conceptions of obligation are conditioned by cultural frameworks that vary systematically across nations (Wuthnow 1991). These frameworks specify social boundaries, namely images of who belongs to the community, and criteria of social worth conventionally used to judge the worthiness or deservingness of others (Lamont and Molnar 2002; Hall and Lamont 2013). In many cases, they reference conceptions of social justice linked to wider frameworks of ideas embodied in folk wisdom about such matters as the role of effort and fortune in people's lives or the value of self-discipline versus self-expression (Lamont 2000). 
Several important points follow from these observations. First, they suggest that redistributive solidarity can be underpinned by both altruism and self-interest, if people are understood to operate from a self-interest enlightened by the institutional and cultural frameworks in which they live. I may support a program that redistributes to others partly because it has the potential to redistribute to me. In other words, self-interest can underpin attitudes of generalized support for a redistributive welfare state. Second, this perspective suggests that the attitudes to redistribution common to any society are rooted in a wider set of institutional frameworks that organize its incentive structures and in cultural frameworks connected to the cognitive, symbolic and normative repertoires that people use to navigate the choices in their lives (Swidler 1986; Markus and Nurius 1986). In many cases, these institutional and cultural frameworks may reinforce one another to create consistent patterns of attitudes analogous to the 'embedded preferences’ described by Brooks and Manza (2007).

Thus, if attitudes to redistribution are conditioned by mutually-reinforcing processes between institutions and cultural frameworks, they may reflect quasi-equilibria of redistributive solidarity that are nationally-specific and relatively-stable over time. Instead of being relatively-evanescent phenomena, susceptible to annual fluctuations in socioeconomic or demographic variables such as levels of income inequality or rates of migration, national attitudes to redistribution may be relatively durable, because they are rooted in cultural and institutional frameworks that change relatively slowly, even though they are susceptible to change. 


\section{Mechanisms behind quasi-equilibria}

What sorts of mechanisms might underpin these quasi-equilibria? The field does not yet have a complete answer to this question but, if we take support for programs that redistribute to the less advantaged as the phenomenon to be explained, the literature points to several mechanisms. In some cases, the shape of prevailing institutions conditions support for such programs; in others, institutions promote wider worldviews that bear on such support.

Some analyses emphasize the ways in which existing levels of social provision condition general support for redistribution. Of course, social programs create a base of support among their beneficiaries, although that is not deeply reflective of social solidarity. But the network externalities generated by such programs can also induce support for them among wider segments of society who are not direct beneficiaries (Pierson 2000). ${ }^{6}$ Moreover, expanding the beneficiaries in some programs may build a generalized support for the welfare state that sustains components that are more redistributive, a phenomenon especially important where the legitimacy of governmental efforts to redistribute income is an object of political competition. Similarly, support based on self-interest for programs that provide equivalent levels of benefits to people across different levels of income often sustain programs whose benefits are worth much more to people at lower levels of income.

Support for redistribution to the disadvantaged can also be affected by the design of social programs. There is evidence, for instance, that programs presented as contributory social 
insurance attract more social support than non-contributory programs, regardless of whether the benefits are funded from those contributions (Larsen 2006; Jaeger 2009). Program design can also reinforce or erode worldviews that are central to redistributive solidarity. By virtue of how they discriminate among the recipients of benefits, for instance, social programs contribute to the drawing of social boundaries (Esping-Andersen 1990; Lamont and Molnar 2002). Thus, some scholars argue that 'universal' programs which distribute benefits widely as a right of citizenship reinforce social solidarity, because they promote the view that every citizen is entitled to social protection (Rothstein 1998). By contrast, means-tested programs tend to stigmatize the poor, singling them out as dependents on society rather than contributors to it - thereby promoting images of the poor as indolent or undeserving, which, in turn, reduce popular support for redistribution (Esping-Andersen 1990; Larsen 2008).

There is controversy about the strength of such effects (Linos and West 2002; Jaeger 2006). However, Jaeger (2009; see also Larsen 2006) presents evidence that the extensive use of meanstested programs in the liberal welfare states of the Anglo-American democracies reduces support for redistribution, while Larsen and Dejgaard (2013) found many more negative images of the poor in the media of Britain, where means-testing is prominent, than in the media of Denmark or Sweden, whose universal social programs promote a rhetoric of social citizenship. Moreover, although racial boundaries can also impinge on support for redistribution, they found that media references to the poor were less negative in the two Nordic nations than in Britain even when the poor were identified as racially distinct (cf. Alesina, Glaeser, and Sacerdote 2001). 
Note that there are some dynamic dimensions to these effects that tend to reinforce quasiequilibria. Where social programs are expansive, contributory or universal enough to foster worldviews supportive of redistribution, redistributive spending is likely to increase, thereby building further support for the welfare state, at least up to some limit. By contrast, where means-tested programs stigmatize the poor, popular support for redistribution is likely to be fragile, making it politically more difficult to expand social programs and easier to cut them back. Over time, ceteris paribus, the effect should be to sustain, if not widen, cross-national differences in the generosity of social policy regimes.

Since the primary responsibility for redistribution in the developed democracies usually falls on governments, support for redistribution can also be affected by the institutional character of the state. There is evidence that, where governments are corrupt, inept or highly particularistic in the delivery of benefits, citizens are less likely to support redistribution (Edlund 1999; Rothstein 2011; Svallfors 2013). At least two mechanisms operate work here. On the one hand, political corruption tends to reduce levels of general social trust, which is widely thought to be a determinant of levels of social solidarity, including support for redistribution (Halvorsen 2007). On the other hand, even when citizens are willing in principle to support redistribution, they may be reluctant to let a state they distrust undertake such tasks. Once again, mutually-reinforcing interactions between institutions and worldviews make it difficult for countries to escape this kind of social trap (Rothstein 2005; Mungiu-Pippidi 2013). The belief that institutions are corrupt renders citizens more likely to engage in corrupt behavior themselves and correspondingly less likely to trust one another. As a result, it becomes more difficult for them to engage in the kinds of collective action necessary to reduce corruption and restore trust. 
There can also be important interaction effects between economic policy regimes or the institutions of the political economy and popular attitudes to redistribution. In a seminal article, Benabou and Tirole (2006) show how a specific set of institutions (in this case policy regimes for taxing and spending) and a particular cultural framework (namely, beliefs about deservingness which they call 'beliefs in a just world') can underpin one another to create quasi-equilibria reflecting two different levels of redistributive solidarity. Their argument turns on a comparison between two stylized country cases.

In one of these cases, which resembles the U.S., policy regimes keep both taxes and social spending low, so there is not much of a social safety net. As it happens (for reasons that might be exogenous), in this country, parents believe and teach their children that what one gets in the world is mainly a reflection of one's own efforts. As adults imbued with this worldview, those children will tend to work hard and support keeping taxes low, so they can keep the fruits of their effort, while opposing increases in social spending out of a belief that poverty results from a lack of effort. The resulting policy regimes will then reinforce their beliefs.

In the second case, which resembles Sweden, policy regimes provide generous social benefits sustained by high rates of tax. For these (or exogenous) reasons, parents are less inclined to teach their children that what they get will depend entirely on their own efforts and more inclined to suggest that fortune plays a large role in how one's life turns out. As adults equipped with such beliefs, those children will be more inclined to rely on the social safety net and to associate poverty with bad luck rather than a lack of effort. As a result, they will provide more political 
support for generous social benefits and the taxes required to fund them, which will help sustain those beliefs.

The result is two equilibria in which popular beliefs - about the extent to which income is dependent on effort rather than luck - and institutions - in the form of policy regimes - are mutually reinforcing. In one case, low taxes and a meagre social safety-net promote worldviews resistant to increasing taxes and benefits. In the other, higher taxes and generous benefits promote worldviews that mandate higher levels of redistribution. This argument fits the observation that 60 percent of citizens living in generous European welfare states think income is more dependent on luck than effort, while only 30 percent of Americans do. Moreover, it suggests that very general beliefs (in this case about luck and effort) may be just as important to redistributive politics as explicit policy preferences.

Popular beliefs do not have to be accurate to be consequential. Consider the case of American beliefs about social mobility. Even though American rates of mobility are not especially high and possibly declining, some argue that a widespread belief in the possibility of upward social mobility suppresses support for redistribution in the U.S. (Piketty 1995; Alesina, Di Tella, and MacCulloch 2004; Corak 2013). In such instances, however, where beliefs and institutions are incongruent, levels of support for redistribution may be less stable. There are some indications, for instance, that the precondition for high rates of social mobility may be a generous set of redistributive social programs (Mitnik, Cumberworth, and Grusky 2013). Thus, beliefs about social mobility in the U.S. may be sustaining policies that are gradually undermining the material or institutional basis for such beliefs. 
Indeed, to suggest that support for redistribution turns on institutional and cultural frameworks, rather than on a small number of fluctuating variables, is not to say it is immutable. I use the

term ‘quasi-equilibrium' precisely in order to signal that attitudes to redistribution are susceptible to change as institutions and cultural frameworks shift. We do not yet know much about how such changes take place. However, they seem to do so gradually via processes like Bayesian updating that are heavily biased toward the status quo. Thus, Europeans living under more egalitarian conditions were rendered more upset by increases in income inequality than Americans were, a reaction that might inspire further support for redistribution (Alesina, Di Tella, and MacCulloch 2004; Barnes and Hall 2013). Similarly, Kerr (2013) finds that, when actual levels of income inequality rise, people's views about the appropriateness of differences in income between occupations also shift upward, although that does not entirely suppress support for redistribution (see also Medgyesi 2013).

\section{Empirical implications and evidence}

Is there evidence for this quasi-equilibrium perspective? A full evaluation is beyond the scope of this chapter, but the perspective carries two empirical implications that can be assessed against basic cross-national data. First, if this quasi-equilibrium approach to redistributive solidarity is correct, there should be a certain durability to national attitudes about redistribution. Such attitudes can and do change over long periods of time; but, over the short to medium term, crossnational differences in them should be broadly stable. 
Investigating that proposition involves finding data that is comparable across countries and time in a context where relatively few good indicators are available cross-nationally. We should also note that support for redistribution is a multidimensional phenomenon (Janmaat 2013). Those who favor redistributing from the rich do not always support redistribution toward the poor; and some people want to exclude immigrants or others from such programs (Cavaillé and Trump 2015; McCall 2013).

Therefore, based on Cavaillé (2014), I draw a distinction between general support for redistribution, understood as people’s desires to see incomes made more equal, and a second dimension, i.e., support for redistribution to the poor, understood as people's willingness to redistribute resources to the least advantaged in society. To assess the former, I follow common practice and use the level of agreement with survey questions that ask whether incomes should be made more equal and whether the government has a responsibility for making them more equal. To assess support for redistribution to the poor, following Larsen (2006), I use the percentage of respondents who attribute poverty in their country to structural factors, such as bad luck, injustice or inevitability, as opposed to the personal attributes of the poor, such as lack of willpower or laziness. The premise is that people who attribute poverty to laziness or a lack of willpower should be less willing to redistribute resources to them.

Are cross-national differences in attitudes to redistribution broadly stable? Using national averages, Figure 3 compares general support for redistribution in the ISSP surveys of 1992 and 2009 and support for redistribution to the poor in the Eurobarometer surveys of 1989 and 2007 the longest periods for which I could find comparable data. Although general support for 
redistribution (in panel a) declines slightly in the US, New Zealand and Norway and increases in Russian and Hungary over this 17 year period, it remains relatively stable in most countries (as indicated by proximity to the 45 degree line) and the national ordering of attitudes does not change much. Panel b shows that there is more movement in support for redistribution to the poor over a similar period, marked by some convergence, as support rises in countries where it was initially low and declines where it was higher. The most striking feature is a notable decline in support for redistribution to the poor in Portugal and Britain. But, with those exceptions, the country ordering does not change much.

A second empirical implication follows from the causal mechanisms I have adduced to explain quasi-equilibria of redistributive solidarity. At the cross-national level, we can expect to see wide variation in national attitudes to redistribution, because there is plenty of room for variation in the multiple institutional and cultural frameworks constitutive of such quasi-equilibria. Within that range, however, we should observe what can be described as 'low solidarity' and 'high solidarity’ equilibria, characterized by relatively low or high levels of support for redistribution. Moreover, because of the ways in which economic and social policy regimes reinforce existing attitudes, support for redistribution should generally be higher in countries where disposable incomes are more equal as a result of redistribution, while support for it should be lower in countries where there is less redistribution and more unequal disposable incomes. This pattern is the opposite of the one predicted by standard political economy models whose premise is that increasing levels of income inequality increases support for redistribution. 
Figure 3 The stability of support for redistribution over time

(a) General support for redistribution

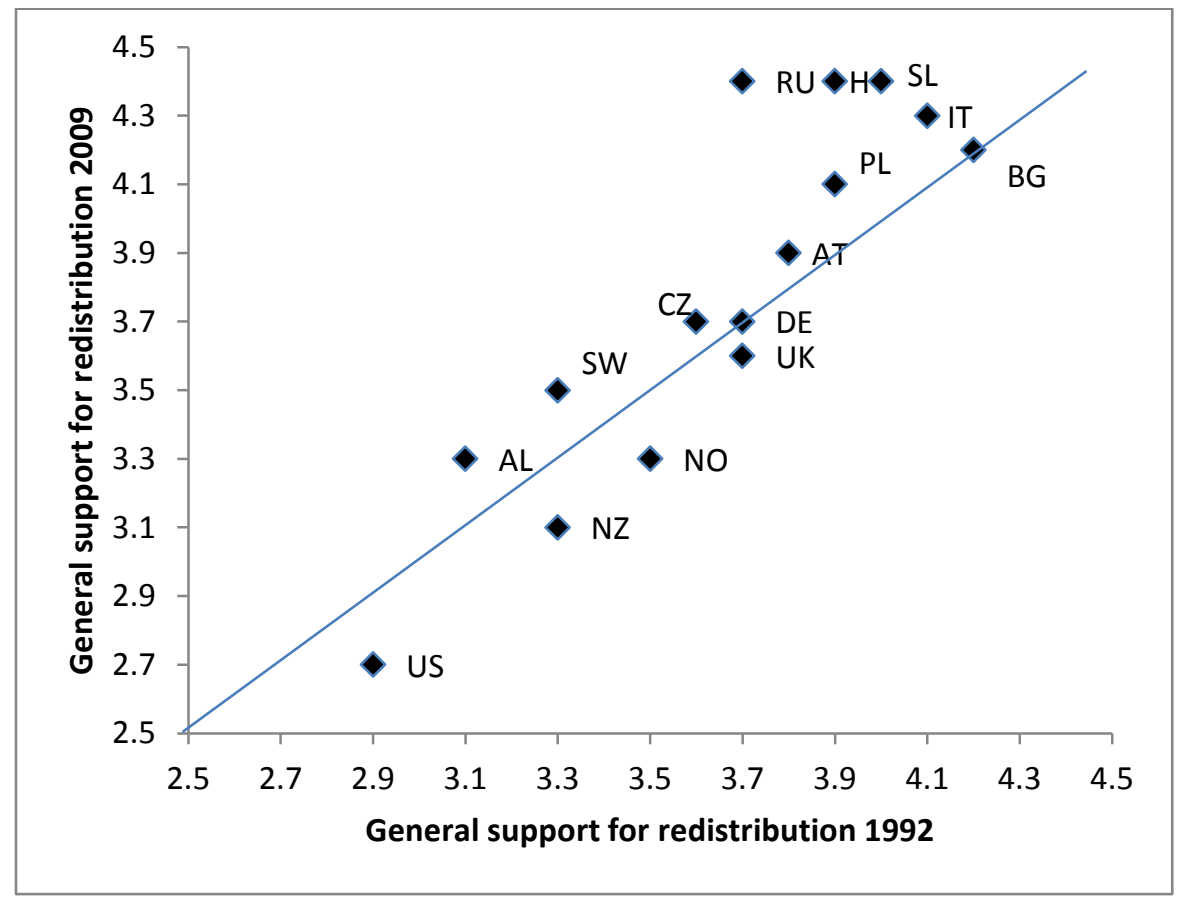

Sources: ISSP (1992, 2009).

(b) Support for redistribution to the poor

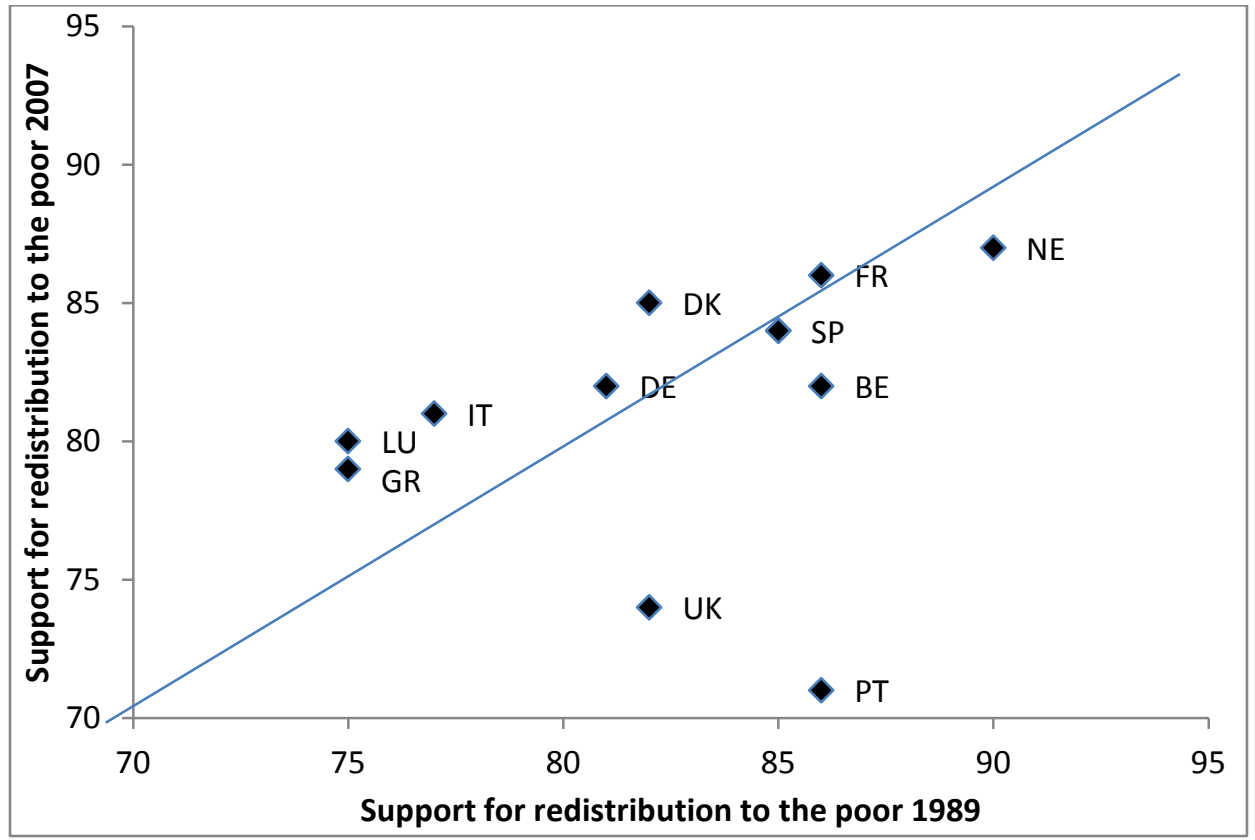

Sources: Eurobarometer 31A (1989) and 279 (2007); For 1989 Germany is West Germany. For 3(a) $\mathrm{R}^{2}=0.80$; $\mathrm{SE}=0.25$. For $3(\mathrm{~b}) \mathrm{R}^{2}=0.08$; $\mathrm{SE}=4.81$. 
Of course, this prediction should be qualified in several ways. Although a quasi-equilibrium perspective suggests that income inequality will not dictate cross-national support for redistribution, inequality may condition that support at the margin; and thermostatic effects that would see support for redistribution decline as redistribution reaches high levels or increase when redistribution falls to very low levels might also affect these patterns (Soroka and Wlezien 2010). But I expect cross-national differences in support for redistribution and inequality in disposable income to be broadly aligned.

Do we observe the high and low solidarity equilibria that this perspective predicts? Figure 4 addresses this issue with a focus on support for redistribution to the poor, arguably a better reflection of redistributive solidarity than general attitudes to redistribution. It is based on the 1990 World Values Survey, which is one of the few sources for data on this topic extending beyond Europe. ${ }^{7}$ The broad direction of the relationship displayed in Figure 4 supports the contention: in countries where national support for redistribution is higher, inequality in disposable income is lower. Although every country occupies a distinctive position in this space, reflecting nationally-specific circumstances, the distribution is anchored by the Nordic countries, Norway, Sweden and Denmark, closely followed by the Netherlands and France, which might be said to reflect 'high solidarity' equilibria, while the United States embodies a 'low solidarity' equilibrium, closely followed by Canada and Britain (see also Paskov and Dewilde 2012). ${ }^{8}$

For an assessment of whether general attitudes to redistribution also reflect this perspective, we can turn back to Figure 1. Here, Russia and Portugal are outlying cases and support for 
redistribution is higher across an arc of East Central European countries but, if they are excepted, national patterns bear some resemblance to those of Figure 4. The U.S. again anchors the low solidarity end of the chart, closely followed by New Zealand, Australia and Canada, while general support for redistribution is higher in countries such as France and Austria where disposable income inequality is lower. On the whole, however, support for redistribution to the poor conforms to these quasi-equilibrium expectations more closely than does general support for redistribution.

Figure 4 The relationship between disposable income inequality and support for redistribution to the poor

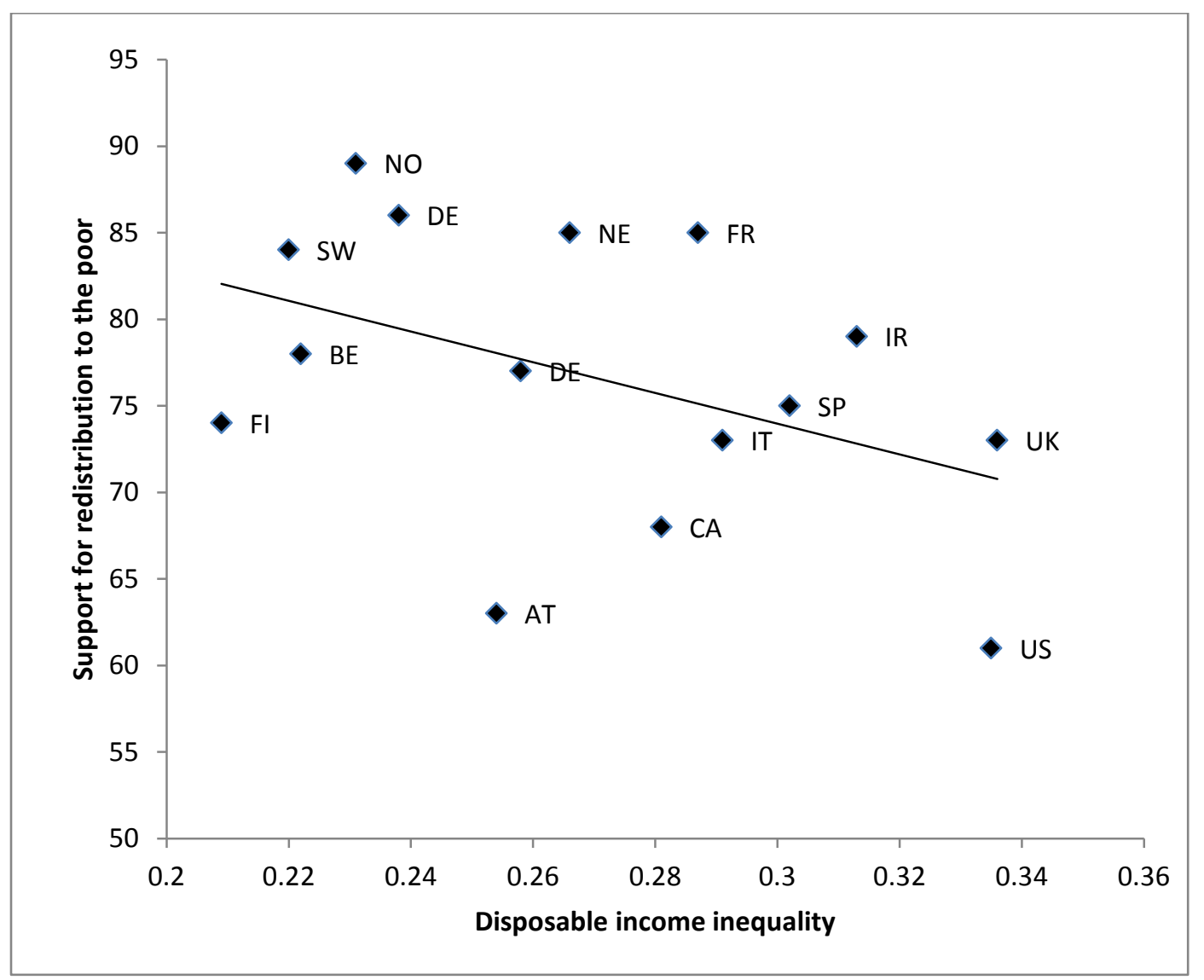

Sources: LIS and World Values Study (1990). $\mathrm{R}^{2}=0.19$; $\mathrm{SE}=7.83$. 
If this quasi-equilibrium perspective helps explain how particular levels of redistributive solidarity are sustained, we must still ask how these quasi-equilibria are generated in the first place - a task to which the next sections turn.

\section{The political construction of social solidarity}

How is redistributive solidarity created? What historical processes give rise to it? A quasiequilibrium approach to solidarity carries implications for the answers to those questions. In particular, it directs our attention to the ways in which the institutions and cultural frameworks underpinning quasi-equilibria were constructed.

Of course, that is also where theories that associate social solidarity with specific conceptions of national identity also take the inquiry. They look for the origins of solidarity in the development of particular forms of national identity - often seen as a highly diffuse process involving the construction of cultural categories and the influence of formative national events (Miller and Ali 2013). In some respects, that is entirely appropriate; but most such accounts construe the relevant cultural frameworks in terms that are overly narrow. To put the core contention succinctly, we need to see that social solidarity flows - not just from national identity per se, whether construed in ethnic, cultural or civic terms - but from visions of social justice that become prominent in national discourse. In some cases, those visions themselves become components of national identity; but we need to look more closely into how that coupling happens and why it takes on 
particular forms if we want to understand the role that national identities play in the process whereby social solidarity is created.

For this purpose, instead of fastening on national identity qua identity, it is useful to consider the broader collective imaginary from which such identities emerge. Hall and Lamont (2009: 12) define collective imaginaries as "sets of representations composed of symbols, myths and narratives that people to portray their community or nation and their own relationship as well as that of others to it” (see also Bouchard 2013). Such imaginaries are a feature of the public sphere in all societies. At their heart are sets of narratives linking a nation's past to its present and specifying its aspirations for the future. Collective imaginaries define the boundaries of membership in the community and offer conceptions of what its members can legitimately demand of others and expect in return. Thus, although more comprehensive than redistributive solidarity per se, these imaginaries bear both on the inclusiveness of the community and on visions of social justice. Among other things, they join popular images of the nation to specific conceptions of social justice. One reflection can be found in familiar notions of the 'American Dream' (Hochschild 1986; Cullen 2003) and another in the organizing ideas of French Republicanism (Jennings 2011; Lamont 2000).

As cultural frameworks, collective imaginaries have a structural quality that lends them durability over time and the potential to affect multiple dimensions of people's worldviews (Sewell 2005). Because they can comprehend competing or ambiguous narratives, these imaginaries are not entirely objects of consensus, but rather repertoires of collective representations that provide the tools out of which contemporary debates are constructed. As 
such, they can push debates in particular directions, and their boundaries circumscribe what is likely to be seen as a legitimate argument. Their power comes partly from how their narratives resonate with the emotional attachments people feel to the nation. But it also resides in the capacities of those imaginaries to condition folk wisdom about such things as what constitutes commendable action and how people make their way in the world, notions that Swidler (1986) terms the 'strategies for action' available to individuals. This folk wisdom may be broadly cognitive in content, but it carries normative implications for issues of redistribution that are all the more influential because the normative content is often implicit rather than explicit (Powell and DiMaggio 1991).

How were the components of such imaginaries relevant to redistributive solidarity constructed? As the literature on the development of the welfare state indicates, in the developed democracies, the answer must be: by historically-important and highly-political movements for social justice. In some cases, as Baldwin (1992) notes, these were largely middle-class movements, such as the one led by Léon Bourgeois in $19^{\text {th }}$ century France (Hayward 1961). In others, they were movements based on cross-class coalitions in which agrarian and Christian Democratic parties played often prominent roles (Swenson 2002; Mares 2003). Religious movements influence the views of their adherents about personal obligation and, through Christian Democratic parties in particular, they have sometimes conditioned national visions of social justice (Lichterman 2005; Manow and van Kersbergen 2009).

Over the twentieth century, however, these movements for social justice have been spearheaded by social democratic parties and the representatives of organized labor (Huber and Stephens 
2001; Bradley et al. 2003; Korpi 2006). Social democratic parties and trade unions contributed to the construction of regimes of solidarity in two ways. On the one hand, they helped put in place social policy regimes that, once institutionalized, fostered on-going support for redistribution. Social democratic parties were especially important to the construction of regimes built on expansive conceptions of social citizenship (Esping-Andersen 1990). On the other hand, as part of an active politics of coalition-building, these parties promoted visions of social justice that left an imprint on national collective imaginaries. Prior to the Second World War, social democratic parties used the term 'solidarity' primarily to refer to class solidarity but, after the war, social democrats began to speak of solidarity as a national value (Stjernø 2004). ${ }^{9}$

Thus, two features of the labor movement were important to cross-national variation in support for redistribution. One was the political strength of trade unions and parties on the political left. Where they commanded more members and votes, more generous and universalistic policy regimes were likely to be put in place. The other was the orientation of the trade unions, namely, whether they construed their mission in broad political terms - as tribunes for the people - or in narrower terms as defenders of their members in the industrial relations arena. Where unions embraced a wider political role, they were more likely to promote generous social programs and advance ideals of social justice.

The orientation of the trade union movement was conditioned by its organization. Where wage bargaining was concentrated at the peak level under the aegis of one powerful confederation, as in Sweden, trade unions tended to mount solidaristic appeals that influenced the wage structures and social policies of many Nordic countries (Iversen 1999; Martin and Thelen 2007). Even in 
the absence of a single powerful confederation, however, if wage bargaining was conducted primarily by national confederations organized along ideological lines, as in France, the trade unions were also more likely to act as tribunes for the people, partly in order to compete with their rivals (Andolfatto and Labbé 2010). By contrast, union appeals tended to be less solidaristic in countries where labor was organized by industrial sector, as in Germany, or where many unions were organized by skill category, as in Britain. In these cases, sectarian wage competition often took precedence over national appeals for social justice.

A full discussion of this point is beyond the scope of the chapter, but Table 1 provides some illustrative support for it. Here, I use the data of Hamann, Johnston, and Kelly (2012) on the incidence of general strikes in Europe to measure the extent to which labor movements mount national appeals for social justice. Union movements that sponsored a general strike in the 19802006 period have been classified as solidaristic (see also Lindvall 2013). Movements are classified as stronger or weaker, based on whether union membership as a percentage of the workforce exceeded the median in the sample in 2000. The cells in the table report the average level of support for redistribution within the national electorate in 2000. ${ }^{10}$ Although other factors could be driving these outcomes, the Table shows that support for redistribution is higher in countries where the orientation of the labor movement is solidaristic, even when trade unions are weak. 
Table 1 The relationship between the power and orientation of trade unions and general support for redistribution

\begin{tabular}{|c|c|c|c|c|c|}
\hline \multirow{3}{*}{\multicolumn{2}{|c|}{ Stronger }} & \multicolumn{4}{|c|}{ Orientation of Trade Unions } \\
\hline & & \multicolumn{2}{|c|}{ Solidaristic } & \multicolumn{2}{|c|}{ Sectoral Defense } \\
\hline & & Austria & 6.4 & Sweden & 5.1 \\
\hline & & Finland & 6.4 & Ireland & 5.1 \\
\hline & & Norway & 5.7 & Denmark & 4.3 \\
\hline & & Belgium & 5.5 & & \\
\hline \multirow{7}{*}{$\begin{array}{l}\text { Power of } \\
\text { Trade Unions }\end{array}$} & & Average & 6.0 & Average & 4.8 \\
\hline & Weaker & France & 6.2 & Germany & 5.6 \\
\hline & & Portugal & 6.1 & UK & 5.4 \\
\hline & & Spain & 5.9 & & \\
\hline & & Italy & 5.0 & & \\
\hline & & Nthlds & 4.9 & & \\
\hline & & Average & 5.6 & Average & 5.5 \\
\hline
\end{tabular}

Note: The figures in each cell report the support for redistribution in that country based on average responses on a ten point scale running from 'income differences should be larger to provide incentives for individual effort' to 'incomes should be made more equal' in 2000. Higher values indicate more support for redistribution.

Sources: European Values Survey (2000); Hamnan, Johnston, and Kelly (2012); ICTWSS Version 4.0.

Of course, other factors affected which types of trade unions and political parties were influential and the kind of appeals they made. Electoral rules mattered: social democratic parties were more successful under systems of proportional representation (PR) than in those operating on firstpast-the-post rules (Iversen and Soskice 2006). Across PR systems, Christian Democratic parties promoting generous but conservative welfare states prospered where religious cleavages were 
prominent in the early $20^{\text {th }}$ century, while social democratic parties fared better in countries where they could form alliances with agrarian parties (Manow and van Kersbergen 2009). In such cases, the need to appeal beyond workers to farmers, who preferred universal benefit schemes because they lacked the employment histories for social insurance, inclined Nordic governments toward the welfare regimes based on social citizenship that built social solidarity. In any one nation, a number of factors could condition the strength and complexion of the relevant political actors, but the underlying point is that redistributive solidarity did not emerge entirely from some primordial understanding of national identity. It was constructed by political actors, campaigning in the name of social justice, who put in place the institutions and encouraged the worldviews that sustain social solidarity.

Moreover, in order to build coalitions for this purpose, political leaders often tied their programs to particular images of the nation. In this respect, the process whereby welfare states were built can be seen as a distinctive stage in nation-building - one in which specific ideals of social justice were built into the imagery of the nation at the same time as they were being institutionalized into the frameworks of national social programs. At critical moments in the politics of social policy, national collective imaginaries were inflected in ways that consolidated or redrew social boundaries, redefined the rights associated with citizenship, and re-specified the obligations of individuals to the community (Béland and Lecours 2005). The resulting amalgam of national images and ideals of social justice became a basis for social solidarity in the nation.

Sweden is a paradigmatic case. In 1928, when Per Albin Hansson became leader of its influential social democratic party, the SAP, he confronted the challenge of how to mobilize support for the 
party’s egalitarian social program. Faced with a small industrial sector and substantial agrarian population, he could not build a large enough coalition on appeals to class solidarity. Instead, he decided to present his party's aspirations as an effort to build a certain kind of nation, which he described as the 'people’s home' (folkhemmet). In his words:

The basis of the home is community and togetherness. The good home does not recognize any privileged or neglected members, nor any favorite or stepchildren. In the good home there is equality, consideration, cooperation and helpfulness. Applied to the great people's and citizens' home this would mean the breaking down of all the social and economic barriers that now separate citizens into the privileged and the neglected, into the rulers and the dependents, into the rich and the poor, the propertied and the impoverished, the plunderers and the plundered. (Berman 1998, 157)

This powerful metaphor was to be a centerpiece of the party's campaigns in ensuing years; and, reiterated by successive social democratic governments, it became an important element in how Swedes began to think about their nation (Tilton 1991; cf. Kettunen 2012). Egalitarian ideals became a part of Swedish identity. The Swedish social democrats reshaped the national collective imaginary in ways that reinforced social solidarity for decades to come.

By contrast, consider how Franklin D. Roosevelt built a coalition for his social policies in the United States at roughly the same time. In many respects, those policies were as radical a break with the past as those of the Swedish SAP (Gourevitch 1986). The Social Security Act of 1935 laid the foundations for the American welfare state. But the political challenges facing Roosevelt 
were quite different. In Congress, his own party was dominated by representatives from the South who were suspicious about federal intervention and unenthusiastic about extending social benefits to African-Americans. Partly for these reasons, agricultural and domestic workers were exempted from some provisions of the Act; and Roosevelt decided to present his program of social benefits as a social insurance scheme, whose legitimacy was based on its actuarial principles rather than on its contribution to social equality (Lieberman 1995; Jacobs 2011; cf. Davies and Derthick 1997). Compare the words of Per Albin Hansson with the speech Roosevelt gave on passage of the Act, when he declared:

This law represents a cornerstone in a structure which is being built but is by no means completed - a structure intended to lessen the force of possible future depressions, to act as a protection to future administrations of the Government against the necessity of going deeply into debt to furnish relief to the needy - a law to flatten out the peaks and valleys of deflation and of inflation - in other words, a law that will take care of human needs and at the same time provide for the United States an economic structure of vastly greater soundness. (Hamen 2010, 75)

The Social Security Act was a triumph of social and political engineering; but it did nothing to overcome the racialized social order that was still a prominent part of the American collective imaginary and little to advance the place of egalitarian ideals in that imaginary (Smith 1999). To this day, racial divisions continue to haunt American debates about social policy (Alesina, Glaeser, and Sacerdote 2001; Steensland 2006). 


\section{Social solidarity in a transnational world}

What are the implications of this analysis for securing a social solidarity in societies marked by more racial, ethnic and religious diversity? This is an important issue at a time when immigration has become a prominent feature of a globalizing world and crucial to the prosperity of many nations with aging populations.

I have argued that redistributive social solidarity takes the form of a quasi-equilibrium underpinned by institutions and cultural frameworks that are deeply-entrenched and mutually reinforcing. These frameworks were constructed over long periods of time and, although susceptible to change, often evolve only gradually. Thus, they constitute important background conditions for countries dealing with higher levels of diversity. One of the implications is that countries that have already developed relatively expansive conceptions of social citizenship, such as those with social democratic welfare states, should be better able to extend redistributive solidarity to immigrants of diverse backgrounds. Conversely, countries whose welfare regimes militate against redistributive solidarity, such as those with liberal welfare states that draw sharper symbolic divisions between recipients of social benefits and other citizens, should find it more difficult to treat new groups of immigrants in solidaristic terms.

Although the issue is far from fully resolved, there is some evidence for this proposition. In the social democratic welfare states of Norway, Denmark, Sweden and Finland, for instance, popular opposition to extending social benefits to immigrants - a set of attitudes often described as 
welfare chauvinism - has been generally been low, although it may be increasing in countries such as Denmark in the wake of recent mass migration (Mewes and Mau 2012; Bay and West Pedersen 2006). Figure 5 indicates that welfare chauvinism has historically been somewhat higher in countries, such as France and Germany, with conservative welfare states based on social insurance principles, but highest of all in liberal welfare states, such as Britain, where means-testing is used to target benefits on the poor. ${ }^{11}$ By contrast, a history of racial, ethnic or religious homogeneity does not seem to promote welfare chauvinism, which is lowest in the Nordic countries that have historically been racially and religiously homogenous. Moreover, the more influential factor seems to be conceptions of the poor rather than general attitudes to inequality. As Figure 5 (panel a) indicates, there is no obvious relationship between general support for redistribution and welfare chauvinism (cf. Reeskens and van Oorschot 2012). However, panel (b) suggests that, in nations where support for redistribution to the poor is higher, welfare chauvinism is lower $\left(\mathrm{R}^{2}\right.$.30). People's willingness to extend redistributive solidarity to new groups is apparently conditioned by the terms on which solidarity has been extended in the past. 
Figure 5 The relationship between support for redistribution and welfare chauvinism

(a) General support for redistribution

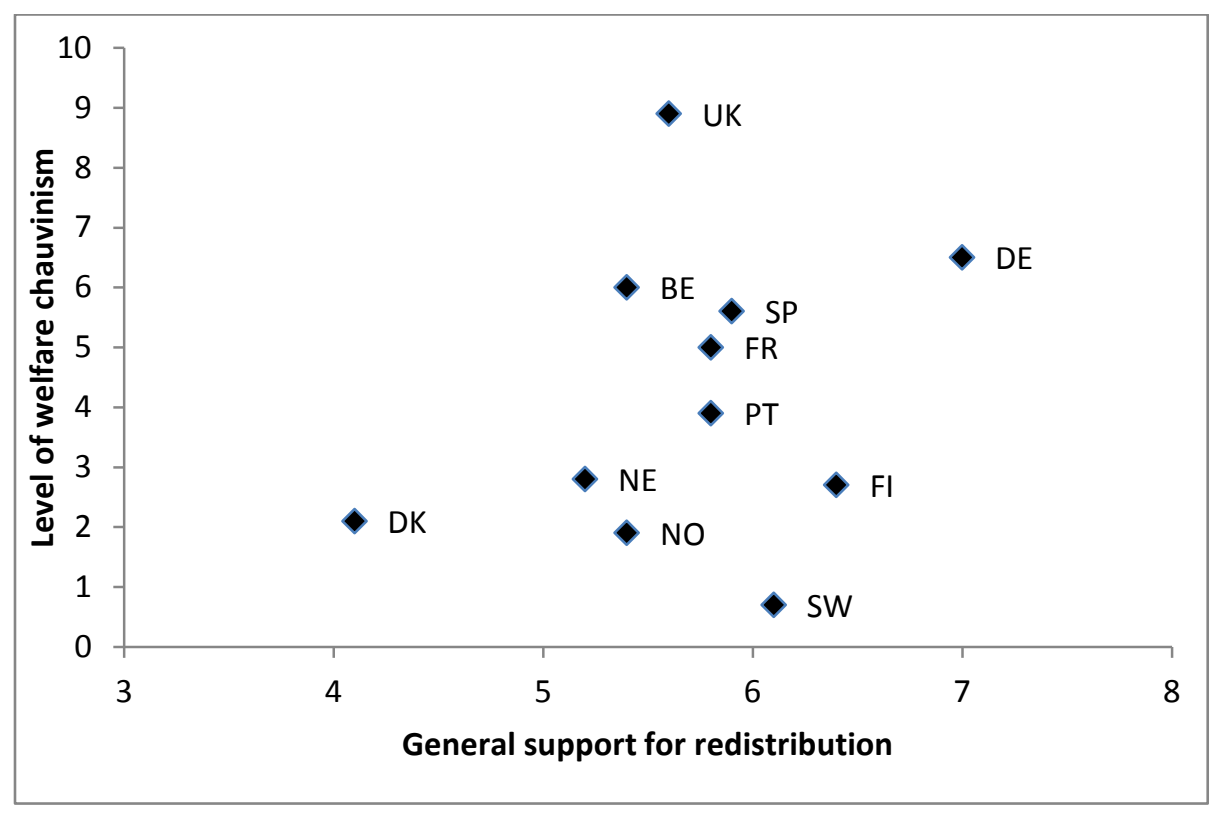

(b) Support for redistribution to the poor

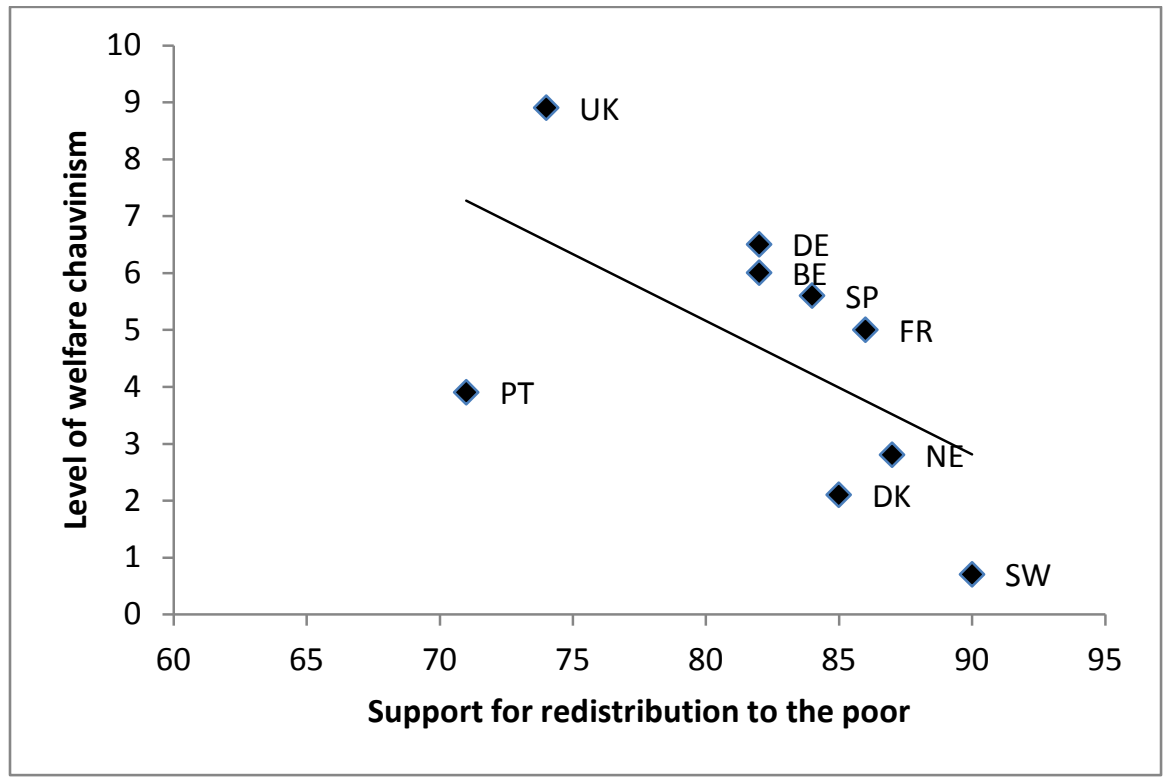

Sources: European Social Survey (2008); European Values Study Round 6 (2008);

Eurobarometer 279 (2007). For 5(a) $R^{2}=0.07 ; \mathrm{SE}=2.48$. For 5(b) $\mathrm{R}^{2}=0.33$; $\mathrm{SE}=2.20$. 
Within these parameters, however, there is still room for social solidarity to change. As we have seen, support for redistribution tends to be higher in countries where there is more redistribution. Therefore, if governments begin to redistribute more generously or more universally, the social solidarity reflected in popular support for redistribution may rise and extend to more diverse groups of people. However, contemporary governments interested in expanding redistribution face serious economic constraints. Social spending increased most rapidly during the 1960s and 1970s when the governments of the developed democracies believed high rates of economic growth would continue, thereby giving them ample revenues from which to redistribute. But rates of economic growth in the OECD countries have fallen by half since the 1970s, and entitlement spending as a share of national budgets has increased dramatically, leaving less room for expansion. Because governments ran deficits to avoid reducing social spending when growth declined, some now face levels of debt that limit their capacities to expand spending further (Schäfer and Streeck 2013).

Partly as a result, instead of moving toward more universal programs that accord benefits as a right of citizenship, many governments have tightened eligibility requirements and begun to target more benefits on the poor - even in some of the Nordic welfare states (Lindblom and Rothstein 2004; Hemerijck 2012). From the perspective of relieving poverty, targeting benefits on the poor is a cost-effective strategy; but it can render redistributive solidarity more fragile by virtue of how it sharpens the symbolic boundaries between benefit recipients and other citizens. It is notable, for instance, that, in the liberal welfare states of Britain and the U.S. which rely heavily on means-testing for social assistance, support for redistribution to the poor has declined, 
even though general attitudes to redistribution have not shifted much despite three decades of rising income inequality (Cavaillé and Trump 2015). As more governments turn toward targeted benefit programs in order to limit their outlays, redistributive solidarity may decline in other countries as well.

Other factors are also contributing to that decline. Higher levels of immigration sometimes reduce support for redistribution, and economic developments play a role (Burgoon 2014; cf. Mewes and Mau 2012). Higher levels of income inequality in the bottom half of the income distribution seem to reduce support for redistribution, as the social distance between the median voter and the poor increases (Lupu and Pontusson 2011). Where income differences are associated with high levels of spatial or social segregation, it may be more difficult for people on average incomes to regard the poor as members of their own community. And rising levels of economic insecurity, linked to the loss of good middle-class jobs, can engender sauve-qui-peut attitudes that militate against redistributive solidarity (Hacker, Rehm, and Schlesinger 2012; Autor and Dorn 2013; Oesch 2013). Mewes and Mau (2012) find, for instance, that one of the best predictors of welfare chauvinism is the extent to which an individual feels economicallyvulnerable (see also Alt 1979).

Moreover, although collective imaginaries have some intrinsic durability, concerted political action may be necessary to sustain them; and, in its absence, they may be vulnerable to changes in contemporary discourse. Iversen and Soskice (2012) find, for instance, that among people with similar incomes trade union members are more likely than non-members to favor redistribution (see also Kumlin and Svallfors 2007). Helbling, Reeskens, and Wright (2013) note that, when 
partly platforms make more nationalist appeals, whether of a civic or ethnic nature, popular hostility to immigrants also increases (see also Cavaillé 2014). Thus, redistributive solidarity may be harder to sustain after three decades marked by the ascendance of a neoliberal rhetoric. That rhetoric downplays issues of social justice and emphasizes market-oriented values such as self-reliance, entrepreneurialism and pay for performance, which permeate the views of ordinary people and militate against programs of generous redistribution (Boltanski and Chiapello 1999; Barnes and Hall 2013). Neoliberal values have also been associated with racial or ethnic prejudice (Son Hing 2013). Although it is difficult to separate out the effects of such factors, some features of contemporary political discourse in the developed democracies may be limiting redistributive solidarity and its extension to more diverse groups.

Moreover, the political voices calling for redistribution are weaker now than they were when the solidaristic social programs of the post-war years were put in place. Since 1980, trade union membership in the OECD has fallen by half, and many unions have turned away from the politics of social justice toward a politics of sectoral defense in order to retain a dwindling membership (Baccaro and Howell 2011; Pontusson 2013). Social democratic parties are still a prominent part of the European landscape, but they have moved even more sharply to the right than their conservative counterparts over the past three decades, (Iversen 2006). In many countries, their electoral base is being sapped by rising parties of the radical right. Although radical right parties have recently become more supportive of redistribution for native-born citizens, they are determined opponents of redistribution to immigrants; and their prominence raises the electoral salience of a narrow nationalism inimical to the extension of redistributive solidarity (Norris 2005; Shayo 2009; Helbling, Reeskens, and Wright 2013). As a result, even 
mainstream parties are hedging on the question of promoting rights for immigrants and ethnic minorities.

Can the European Union serve as an alternative vehicle for the promotion of social solidarity? Its officials have long had that aspiration and the EU has had some success at securing basic rights for migrants. But the financial crisis of the Eurozone and the response of the member governments to it have damaged the wider prospects for European solidarity. Policies of austerity following that crisis have forced cutbacks in redistribution and generated the kind of difficult economic conditions that do not encourage people to support further redistribution to immigrants. Moreover, the political response to the crisis has revealed the limits to social solidarity in Europe. Instead of reacting to the crisis as if the continent were a common community of fate, in which the success of each state depends on the prosperity of all, the creditor countries led by Germany responded in terms that gave priority to their own national interests (Hall 2012, 2014). Pronouncements that laid the blame for the crisis on the debtor countries fed popular stereotypes of 'lazy Greeks' that evoked longstanding images of the undeserving poor. As a result, social solidarity in Europe currently seems to stop at national borders (Pew Research Center 2012).

In this context, one can reasonably ask whether the redistributive solidarity reflected in western welfare states is not an artefact of a specific place and time when trade unions and social democratic parties were especially strong. The factors conducive to solidarity in the developing world are somewhat different, and, even in Europe, it remains an open question whether new vehicles for the promotion of redistributive solidarity will appear with enough influence to 
sustain it (Lieberman 2003; Singh 2015). In Europe and America, the loudest voices currently promoting social solidarity across ethnic, racial and religious lines are non-governmental and quasi-governmental organizations, such as the Council of Europe (2012). They have gained new momentum and influence in an era of social media, not least because their appeals resonate with a venerable set of western values. But it is not clear they can sustain redistributive solidarity amidst a cacophony of voices that challenge it.

Of course, there is also some support for according social benefits to immigrants at official levels, notably in ministries of social services and the judiciary, which have long been institutional enclaves for such values (Guiraudon 2000). In a few countries, judicial decisions have been crucial to securing social benefits for immigrants, and Ferwerda (2014) shows that such decisions can reshape political dynamics. Where courts mandate social benefits for immigrants, thereby taking the issue off the political agenda, political parties are more willing to liberalize citizenship requirements in the hope of securing the votes of such groups. Many European countries provide resources to immigrants through official channels such as these that operate under the radar screen of national politics.

However, is this kind of social solidarity by stealth really social solidarity? Some might say that the solidarity of a nation can be assessed by the level of resources it distributes to those in need. But, in the terms of this volume, social solidarity is embodied in the attitudes of the populace rather than in levels of public provision. As such, it is a social construction, produced over long periods of time by historic struggles about social justice that are a dimension of nation-building and sustained by the institutions and cultural frameworks that emerge from this process. 
However, even when they have mutually-reinforcing qualities, institutions and cultural frameworks can decay without periodic efforts to mobilize support for them (Thelen 2004). Thus, like all such constructions, solidarity is vulnerable to the vicissitudes of history; it will ultimately be maintained and extended to more diverse communities only if social and political leaders continue to argue for inclusive visions of social justice. 


\section{References}

Abizadah, Arash. 2002. "Does Liberal Democracy Presuppose a Cultural Nation? Four Arguments.” American Political Science Review 96: 495-509.

Alesina, Alberto, Edward Glaeser, and Bruce Sacerdote. 2001. "Why Doesn't the US Have a European-Style Welfare State.” Brookings Papers on Economic Activity 2: 187-277.

Alesina, Alberto, Rafael Di Tella, and Robert MacCulloch. 2004. "Inequality and Happiness: Are Europeans and Americans Different?” Journal of Public Economics 88: 2009-42.

Alt, James. 1979. The Politics of Economic Decline. NY: Cambridge University Press.

Andolfatto, Dominique, and Dominique Labbé. 2010. Histoire des Syndicats 1906-2010. Paris: Seuil.

Autor, David H., and David Dorn. 2013. "The Growth of Low-Skilled Jobs and the Polarization of the American Labor Market.” American Economic Review 103: 1553-97.

Baccaro, Lucio, and Chris Howell. 2011 "A Common Neoliberal Trajectory: The Transformation of Industrial Relations in Advanced Capitalism.” Politics and Society 39 (4): 521-63.

Baldwin, Peter. 1992. The Politics of Social Solidarity. NY: Cambridge University Press.

Barnes, Lucy, and Peter A. Hall. 2013. "Social Resilience and Well-Being in the Developed Democracies.” In Social Resilience in the Neoliberal Era, edited by Peter A. Hall and Michèle Lamont, 209-38. NY: Cambridge University Press.

Bay, Heléne and Axel West Pedersen. 2006. "The Limits of Social Solidarity: Basic Income, Immigration and the Legitimacy of the Universal Welfare State," Acta Sociologica 49 (4): 41936.

Béland, Daniel, and André Lecours. 2005. "The Politics of Territorial Solidarity: Nationalism and Social Policy Reform in Canada, the United Kingdom and Belgium." Comparative Political Studies 38 (6): 676-703.

Benabou, Roland, and Jean Tirole. 2006. "Beliefs in a Just World and Redistributive Politics." Quarterly Journal of Economics (May): 699-746.

Berman, Sheri. 1998. The Social Democratic Moment: Ideas and Politics in the Making of Interwar Europe. Cambridge: Harvard University Press.

Blanchard, Olivier. 2004. “The Economic Future of Europe.” Journal of Economic Perspectives 18: 3-26.

Boltanksi, Luc, and Eve Chiapello. 1999. Le Nouvel Esprit du Capitalisme. Paris: Gallimard. 
Bonikowski, Bart. 2013. "Varieties of Popular Nationalism in Modern Democracies: An Inductive Approach to Comparative Research on Popular Culture." Weatherhead Center for International Affairs Working Paper, Harvard University.

Bouchard, Gérard. 2013. National Myths: Constructed Pasts, Contested Presents. London: Routledge.

Bradley, David, Evelyne Huber, Stephanie Moller, François Nielsen, and John D. Stephens. 2003. "Distribution and Redistribution in Postindustrial Democracies." World Politics 55 (2): 193-228.

Brooks, Clem and Jeff Manza. 2007. Why Welfare States Persist. Chicago: University of Chicago Press.

Burgoon, Brian. 2014. "Immigration, Integration and Support for Redistribution in Europe." World Politics 66 (3): 365-405.

Cavaillé, Charlotte. 2014. "Demand for Redistribution in the Age of Inequality.” Doctoral Dissertation, Department of Government, Harvard University.

Cavaillé, Charlotte, and Kris-StellaTrump. 2015. "The Two Facets of Social Policy Preferences.” Journal of Politics 77 (1): 146-60.

Corak, Miles. 2013. "Income Inequality, Equality of Opportunity and Intergenerational Mobility.” Journal of Economic Perspectives 27 (3): 79-102.

Council of Europe. 2012. "Shared Social Responsibility: Putting Theory into Practice.” A special issue of Trends in Social Cohesion No. 24.

Cullen, Jim. 2003. The American Dream: A Short History of an Idea that Shaped a Nation. New York: Oxford University Press.

Dallinger, Ursula. 2010. "Public Support for Redistribution: What Explains Cross-National Differences.” Journal of European Social Policy 20 (4): 333-49.

Davidov, Eldad. 2009. "Measurement Equivalence of Nationalism and Constructive Patriotism in the ISSP: 34 Countries in a Comparative Perspective.” Political Analysis 17 (1): 64-82.

Davies, Gareth, and Martha Derthick. 1997. "Race and Social Welfare Policy: The Social Security Act of 1935.” Political Science Quarterly 112 (2): 217-35.

Edlund, Jonas. 1999. "Trust in Government and Welfare Regimes: Attitudes to Redistribution and Financial Cheating in the USA and Norway." European Journal of Political Research 35: $341-70$. 
Esping Andersen, Gosta. 1990. Three Worlds of Welfare Capitalism. Princeton: Princeton University Press.

Ferwerda, Jeremy. 2014. "Benefits and Ballots: Explaining Party Preferences on Citizenship Policy.” Working Paper, Department of Political Science, Massachusetts Institute of Technology.

Finseraas, Henning. 2008. "Income Inequality and the Demand for Redistribution: A Multilevel Analysis of European Public Opinion.” Scandinavian Political Studies 32 (1): 94-119.

Gourevitch, Peter A. 1986. Politics in Hard Times. Ithaca: Cornell University Press.

Guiraudon, Virginie. 2000. Les politiques de l'immigration en Europe: Allemagne, France, Pays-Bas. Paris: Editions L’Harmatton.

Habermas, Jürgen. 2001. Postnational Constellation. Cambridge: MIT Press.

Hacker, Jacob, Philipp Rehm and Mark Schlesinger. 2012. "Insecure Alliances: Risk, Inequality, and Support for the Welfare State.” American Political Science Review 106 (2): 386-406.

Hall, Peter A. 2005. "Preference Formation as a Political Process: The Case of European Monetary Union.” In Preferences and Situations: Perspectives from Rational Choice and Historical Institutionalism, edited by Ira Katznelson and Barry Weingast, 129-60. New York: Russell Sage Foundation.

Hall, Peter A. 2010. "Historical Institutionalism in Rationalist and Sociological Perspective.” In Explaining Institutional Change: Ambiguity, Agency, Power, edited by James Mahoney and Kathleen Thelen, 204-23. New York: Cambridge University Press.

Hall, Peter A. 2012. "The Economics and Politics of the Euro Crisis.” German Politics 24 (1): $355-71$.

Hall, Peter A. 2013. "Renewal in the Post-Crisis Landscape: The Limits of Technocratic Social Democracy." In Progressive Politics after the Crash, edited by O. Crame, P. Diamond, and M. McTernan, 19-34. London: IB Tauris.

Hall, Peter A. 2014 "Varieties of Capitalism and the Euro Crisis." West European Politics 37 (6): 1223-43.

Hall, Peter A., and Michèle Lamont. 2009. Successful Societies: How Culture and Institutions Affect Health. NY: Cambridge University Press.

Hall, Peter A., and Michèle Lamont. 2013a. Social Resilience in the Neoliberal Era. NY: Cambridge University Press.

Hall, Peter A., and Michèle Lamont. 2013b. "Why Social Relations Matter for Politics and Successful Societies." Annual Review of Political Science 16: 49-71. 
Hall, Peter A., and David Soskice. 2001. Varieties of Capitalism: The Institutional Foundations of Comparative Advantage. Oxford: Oxford University Press.

Halvorsen, Kurt. 2007. "Legitimacy of Welfare States in Transitions from Homogeneity to Multiculturality: A Matter of Trust.” In Social Justice, Legitimacy and the Welfare State, edited by Steffen Mau and Benjamin Veghte, 239-60. Aldershot: Ashgate.

Hamann, Kerstin, Alison Johnston, and John Kelly. 2012. "Unions against Governments: Explaining General Strikes in Western Europe, 1980-2006.” Comparative Political Studies 46 (9): 1030-57.

Hamen, Susan E. 2010. The New Deal. Edina, MN: ABDO Publishing.

Häusermann, Silja, and Hanna Schwander. 2010. "Varieties of Dualism: Labour Market Segmentation and Insider-Outsider Divides.” Paper presented to a Conference on the Dualization of European Societies at the University of Oxford, January.

Hayward, J. E. S. 1961. "The Official Philosophy of the French Third Republic: Leon Bourgeois and Solidarism.” International Review of Social History 6 (1): 19-48.

Heath, Anthony, Jean Martin, and Thees Spreckelsen. 2009. "Cross-national Comparability of Survey Attitudes Measures.” International Journal of Public Opinion Research 21 (3): 293-315.

Helbling, Marc, Tim Reeskens, and Matthew Wright. 2013. “The Mobilization of Identities: A Study on the Relationship between Elite Rhetoric and Public Opinion on National Identity in the Developed Democracies.” Paper presented to the Annual Meeting of the Canadian Political Science Association.

Hemerijck, Anton. 2012. Changing Welfare States. Oxford: Oxford University Press.

Higonnet, Patrice. 2007. Attendant Cruelties: Nation and Nationalism in American History. NY: Other Press.

Hochschild, Jennifer. 1986. What's Fair: American Beliefs about Distributive Justice. Cambridge, MA: Harvard University Press.

Huber, Evelyne, and John D. Stephens. 2001. Development and Crisis of the Welfare State: Parties and Policies in Global Markets. Chicago: University of Chicago Press.

Iversen, Torben. 1999. Contested Economic Institutions. New York: Cambridge University Press.

Iversen, Torben. 2006. “Class Politics is Dead! Long Live Class Politics! A Political Economy Perspective on the New Partisan Politics.” APSA-CP Newsletter 17 (20): 1-6. 
Iversen, Torben, and David Soskice. 2006. "Electoral Institutions and the Politics of Coalitions: Why Some Democracies Redistribute More than Others.” American Political Science Review 100 (2): 165-81.

Iversen, Torben, and David Soskice. 2012. "Information, Social Networks and Interest-Based Voting: Consequences for Distributive Politics.” Welfare Societies Working Paper No. 06/2012, University of Bremen.

Iversen, Torben, and Anne Wren. 1998. “Equality, Employment and Budgetary Restraint.” World Politics 50 (July): 507-46.

Jacobs, Alan. 2011. Governing for the Long Term: Democracy and the Politics of Investment. NY: Cambridge University Press.

Jaeger, Mads Meier. 2006. "Welfare Regimes and Attitudes towards Redistribution: The Regime Hypothesis Revisited.” European Sociological Review 22 (2): 157-70.

Jaeger, Mads Meier. 2009. "United but Divided: Welfare Regimes and the Level and Variance in Public Support for Redistribution.” European Sociological Review 25 (6): 723-37.

Janmaat, Jan Germen. 2013. "Subjective Inequality: A Review of International Comparative Studies on People’s Views about Inequality.” European Journal of Sociology 54 (3): 357-89.

Jennings, Jeremy. 2011 “Equality.” In The French Republic: History, Values, Debates, edited by Edward Berensen, Vincent Duclert and Christophe Prochasson, 103-11. Ithaca: Cornell University Press.

Johnston, Richard, Keith Banting, Will Kymlicka, and Stuart Soroka. 2010. "National Identity and Support for the Welfare State.” Canadian Journal of Political Science 43: 349-77.

Kenworthy, Lane, and Leslie McCall. 2008. "Inequality, Public Opinion and Redistribution.” Socioeconomic Review 6: 35-68.

Kenworthy, Lane, and Jonas Pontusson. 2005. "Rising Inequality and the Politics of Redistribution in Affluent Countries.” Perspectives on Politics 3 (3): 449-71.

Kerr, William R. 2013. "Income Inequality and Social Preferences for Redistribution and Compensation Differentials.” Bank of Finland Research Discussion Paper 31.

Kettunen, Paul. 2012. "Reinterpreting the Historicity of the Nordic Model.” Nordic Journal of Working Life Studies 2 (4): 21-43.

Korpi, Walter. 2006. "Power Resources and Employer-Centered Approaches in Explanations of Welfare States and Varieties of Capitalism: Protagonists, Consenters, and Antagonists.” World Politics 58 (2): 167-206. 
Kumlin, Saffan, and Stefan Svallfors. 2007. "Social Stratification and Political Articulation: Why Attitudinal Class Differences Vary Across Countries.” In Social Justice, Legitimacy and the Welfare State, edited by Steffen Mau and Benjamin Veghte, 19-46. Aldershot: Ashgate.

Kymlicka, Will. 2001. Politics in the Vernacular: Nationalism, Multiculturalism and Citizenship. Oxford: Oxford University Press.

Lamont, Michèle. 2000. The Dignity of Working Men. Cambridge: Harvard University Press.

Lamont, Michèle, and Virag Molnar. 2002. "The Study of Boundaries in the Social Sciences.” Annual Review of Sociology 28: 167-95.

Larsen, Christian Albrekt. 2006. The Institutional Logic of Welfare Attitudes. Aldershot: Ashgate.

Larsen, Christian Albrekt. 2008. “The Institutional Logic of Welfare Attitudes: How Welfare Regimes Influence Public Support.” Comparative Political Studies 41 (2): 45-68.

Larsen, Christian Albrekt, and Thomas Engel Dejgaard. 2013. "The Institutional Logic of Images of the Poor and Welfare Recipients: A Comparative Study of British, Swedish and Danish Newspapers.” Journal of European Social Policy 23 (3): 287-99.

Lichterman, Paul. 2005. Elusive Togetherness: Church Groups Trying to Bridge America's Divisions. Princeton: Princeton University Press.

Lieberman, Evan. 2003. Race and Regionalism in the Politics of Taxation in Brazil and South Africa. New York: Cambridge University Press.

Lieberman, Robert C. 1995. "Race, Institutions and the Administration of Social Policy.” Social Science History 19: 511-42.

Lindbom, Anders, and Bo Rothstein. 2004. "The Mysterious Survival of the Swedish Welfare State.” Paper presented to the Annual Meeting of the American Political Science Association, Chicago.

Lindvall, Johannes. 2013. “Union Density and Political Strikes.” World Politics 65 (3): 539-69.

Linos, Katerina, and Martin West. 2003. "Self-interest, Social Beliefs, and Attitudes to Redistribution. Re-addressing the Issue of Cross-national Variation.” European Sociological Review 19 (4): 393-409.

Lübker, M. 2007. "Inequality and the Demand for Redistribution: Are the Assumptions of the New Growth Theory Valid.” Socio-Economic Review 5: 117-48.

Lupu, Noam, and Jonas Pontusson. 2011. "The Structure of Inequality and the Politics of Redistribution.” American Political Science Review 105 (2): 316-36. 
Manow, Philip, and Kees van Kersbergen, eds. 2009. Religion, Class Coalitions and Welfare States. NY: Cambridge University Press.

March, James, and Johan Olsen. 1989. Rediscovering Institutions: The Organizational Basis of Politics. New York: Free Press.

Mares, Isabela. 2003. The Politics of Social Risk. NY: Cambridge University Press.

Markus, Hazel, and Paula Nurius. 1986. “Possible Selves.” American Psychologist 41: 954-69.

Marshall, T. H. 1950. Citizenship and Social Class and other Essays. Cambridge: Cambridge University Press.

Martin, Cathie Jo, and Kathleen Thelen. 2007. "The State and Coordinated Capitalism: The Contributions of the Public Sector to Social Solidarity in Postindustrial Societies.” World Politics 60 (1): 1-36.

McCall, Leslie. 2013. The Undeserving Rich: American Beliefs about Inequality, Opportunity and Redistribution. NY: Cambridge University Press.

Medgyesi, Márton. 2013. "Increasing Income Inequality and Attitudes to Inequality: A Cohort Perspective.” GINI Discussion Paper No. 94.

Meltzer Alan H., and Scott F. Richard. 1981. "A Rational Theory of the Size of Government.” Journal of Political Economy 89: 914-27.

Mewes, Jan, and Steffen Mau. 2012. “Unraveling Working-Class Welfare Chauvinism.” In Contested Welfare States: Welfare Attitudes in Europe and Beyond, edited by Stefan Svallfors, 119-57. Stanford: Stanford University Press.

Miller, David. 1995. On Nationality. Oxford: Clarendon Press.

Miller, David, and Sundas Ali. 2013. “Testing the National Identity Argument.” European Political Science Review 6 (2): 237-59.

Mitnik, Pablo A., Erin Cumberworth, and David B. Grusky. 2013. "Social Mobility in a High Inequality Regime.” Discussion Paper. Stanford Center on Poverty and Inequality, Stanford University, Stanford, CA.

Mungiu-Pippidi, Alina. 2013. “Controlling Corruption through Collective Action.” Journal of Democracy 24 (1): 101-15.

Norris, Pippa. 2005. Radical Right: Voters and Parties in the Electoral Market. NY: Cambridge University Press. 
Oesch, Daniel. 2013. Occupational Change in Europe. Oxford: Oxford University Press.

Osberg, Lars, and Tim Smeeding. 2006. "Fair Inequality? Attitudes towards Pay Differentials: the United States in Comparative Perspective.” American Sociological Review 71 (3): 450-73.

Paskov, Marii, and Caroline Dewilde. 2012. "Income Inequality and Solidarity in Europe.” Research in Social Stratification and Mobility 30 (4): 415-32.

Pehrson, Samuel, Vivian L. Vignoles, and Rupert Brown. 2009. "National Identification and Anti-Immigrant Prejudice: Individual and Contextual Effects of National Definitions." Social Psychology Quarterly 72 (1): 24-38.

Pew Research Center. 2012. European Unity on the Rocks. Washington: Pew Research Center.

Pierson, Paul. 2000. "Increasing Returns, Path Dependence and the Study of Politics." American Political Science Review 94 (2): 251-67.

Piketty, Thomas. 1995. "Social Mobility and Redistributive Politics.” Quarterly Journal of Economics 110 (3): 551-84.

Pontusson, Jonas. 2013. “Unionization, Inequality and Redistribution.” British Journal of Industrial Relations 51 (4): 797-825.

Powell, Walter W., and Paul J. DiMaggio, eds. 1991. The New Institutionalism in Organizational Analysis. Chicago: University of Chicago Press.

Reeskens, Tim, and Marc Hooghe. 2010. "Beyond the Civic-Ethnic Dichotomy: Investigating the Structure of Citizenship Concepts across 33 Countries.” Nations and Nationalism 16 (4): 579-97.

Reeskens, Tim, and Wim van Oorschot. 2012. "Disentangling the 'New Liberal Dilemma': On the Relation between General Welfare Redistribution Preference and Welfare Chauvinism." International Journal of Comparative Sociology 52 (2): 120-39.

Rothstein, Bo. 1998. Just Institutions Matter. Cambridge: Cambridge University Press.

Rothstein, Bo. 2005. Social Traps and the Problem of Trust. NY: Cambridge University Press.

Rothstein. Bo. 2011. The Quality of Government: Corruption, Social Trust and Inequality in Comparative Perspective. Chicago: University of Chicago Press.

Rueda, David. 2005. "Insider-Outsider Politics in Industrialized Democracies: The Challenge to Social Democratic Parties.” American Political Science Review 99 (1): 61-74.

Schäfer, Armin, and Wolfgang Streeck, eds. 2013. Politics in the Age of Austerity. Oxford: Polity Press. 
Sewell, William H. Jr. 2005. Logics of History: Social Theory and Social Transformation. Chicago: University of Chicago Press.

Shayo, Moses. 2009. “A Model of Social Identity with an Application to Political Economy, Nation, Class and Redistribution.” American Political Science Review 103: 147-74.

Singh, Prerna. 2015. How Solidarity Works for Welfare: Subnationalism and Social Development in India. New York: Cambridge University Press.

Smith, Rogers. 1999. Civic Ideals: Conflicting Visions of Citizenship in US History. New Haven: Yale University Press.

Son Hing, Leanne. 2013. “Stigmatization, Neoliberalism and Resilience.” In Social Resilience in the Neoliberal Era, edited by Peter A. Hall and Michèle Lamont, 158-82. NY: Cambridge University Press.

Soroka, Stuart, and Christopher Wlezien. 2010. Degrees of Democracy: Politics, Public Opinion and Policy. NY: Cambridge University Press.

Staerklé, Christian, Tiina Likki, and Régis Scheidegger. 2012. “A Normative Approach to Welfare Attitudes.” In Contested Welfare States: Welfare Attitudes in Europe and Beyond, edited by Stefan Svallfors, 81-118. Stanford: Stanford University Press.

Steensland, Brian. 2006. "Cultural Categories and the American Welfare State: The Case of Guaranteed Income Policy.” American Journal of Sociology 111 (5): 1273-326.

Stjernø, Steinar. 2004. Solidarity in Europe: The History of an Idea. Cambridge: Cambridge University Press.

Svallfors, Stefan. 1997. "Worlds of Welfare and Attitudes to Redistribution: A Comparison of Eight Western Nations.” European Sociological Review 13 (3): 283-304.

Svallfors, Stefan, ed. 2012. Contested Welfare States: Welfare Attitudes in Europe and Beyond. Stanford: Stanford University Press.

Svallfors, Stefan. 2013. "Government Quality, Egalitarianism and Attitudes to Taxes and Spending.” European Political Science Review 5 (3): 363-80.

Swenson, Peter. 2002. Capitalists Against Markets. NY: Oxford University Press.

Swidler, Ann. 1986. “Culture in Action: Symbols and Strategies.” American Sociological Review 51: 273-86.

Tamir, Yael. 1993. Liberal Nationalism. Princeton: Princeton University Press. 
Theiss-Morse, Elizabeth. 2009. Who Counts as an American? The Boundaries of National Identity. NY: Cambridge University Press.

Thelen, Kathleen. 2006. How Institutions Evolve. New York: Cambridge University Press.

Tilton, Timothy. 1991. The Political Theory of Swedish Social Democracy. Oxford: Oxford University Press.

Wright, Matthew, and Tim Reeskens. 2013. "Of What Cloth are the Ties that Bind? National Identity and Support for the Welfare State across 29 European Countries.” Journal of European Public Policy 20 (10): 1443-63.

Wuthnow, Robert. 1991. Acts of Compassion: Caring for Others and Helping Ourselves. Princeton: Princeton University Press. 


\section{Acknowledgements}

For comments on earlier versions, I am grateful to Keith Banting, Marius Busemeyer, Charlotte Cavaillé, Mareike Kleine, Will Kymlicka, Nicola Lacey, Christian Albrekt Larsen, Jane Mansbridge, Waltraud Schelkle, Anna Skarpelis, Rosemary Taylor and the members of the CIFAR Successful Societies program. Revision of this chapter was supported by a World Politics Fellowship at Princeton University.

\section{Notes}

${ }^{1}$ This measure for general support for redistribution reports average national responses to adjacent questions in the 1999 ISSP cross-national survey that ask whether respondents agree or disagree (on a five point scale) that income inequality is too high and that the government has a responsibility for reducing it. For a discussion of the measure's validity, see Dallinger (2010).

${ }^{2}$ On distinctions among types of national identity, see also Reeskens and Hooghe (2010); Helbling, Reeskens, and Wright (2013); and Bonikowski (2013).

${ }^{3}$ The indicators are based on the criteria people see as most important for being [nationality]. The measure for ethnic identity loads more heavily on native birth, longstanding residence, having citizenship and subscribing to the country's dominant religion, while the measure for civic identity loads more heavily on respect for the country's political institutions, speaking its language and feeling [nationality]. For further description, see Helbling, Reeskens, and Wright (2013). Note that national averages have to be used with caution as indicators because they can hide different national distributions of opinion (Davidov 2009; Heath, Martin, and Spreckelsen 2009; and Osberg and Smeeding 2006).

${ }^{4}$ For civic identity, this accords with the individual-level results of Wright and Reeskens (2013), although they find a relationship between ethnic identity and attitudes to redistribution.

${ }^{5}$ This is one of the few indicators for assessing support for redistribution to the poor available across multiple country cases that extend beyond Europe. In national cases, it correlates highly with support for policies of social assistance specifically directed at the poor. For more details about it and a rationale, see Larsen (2006) and p. 365 below. Here, it is drawn from a 2001 Eurobarometer.

${ }^{6}$ Social insurance programs, for instance, can inspire support, not only among the financial institutions, insurance companies and others involved in their administration, but also among others whose investments turn on expectations about the behavior of others that is dependent on the existence of such programs.

${ }^{7}$ As noted, the measure is the percentage of respondents who attribute poverty to structural factors rather than to the laziness or lack of willpower of the poor. 
${ }^{8}$ Austria is an outlier, which may reflect data issues since reported support for redistribution to the poor there was at least 15 percentage points higher in several surveys conducted in the 2000s than in this 1990 survey.

${ }^{9}$ The importance of trade unions and social democratic parties is highlighted by power-resource theories advanced to explain the development of the welfare state (Bradley et al. 2003). But those theories emphasize social spending, while I am also interested in how the campaigns of these organizations shift the symbolic repertoires and discursive frameworks of national collective imaginaries.

${ }^{10}$ Support for redistribution is measured here by the level agreement on a ten point scale with the statement that incomes should be made more equal versus the statement that income differences should be larger to provide incentives for individual effort.

${ }^{11}$ Welfare chauvinism is measured here by the national percentage of respondents to the European Social Survey of 2008 who said immigrants should never get the same social benefits as native citizens even after they have become citizens or fulfilled other requirements. General support for redistribution reflects the average national score on a ten-point scale in which respondents to the European Values Survey of 2008 were asked whether incomes should be made more equal or income differences should be larger to provide incentives for effort. Support for redistribution to the poor is measured by the national percentage of respondents to a 2007 Eurobarometer survey who ascribed poverty to structural factors rather than the laziness of the poor. 